\title{
Glimpses into the Life of an Engineer, Scholar and Public Intellectual
}

Anand Teltumbde in Conversation with Roland Lardinois, November 2013-January 2019

Roland Lardinois

\section{(2) OpenEdition}

\section{Journals}

\section{Electronic version}

URL: http://journals.openedition.org/samaj/5021

DOI: 10.4000/samaj.5021

ISSN: $1960-6060$

\section{Publisher}

Association pour la recherche sur l'Asie du Sud (ARAS)

\section{Electronic reference}

Roland Lardinois, « Glimpses into the Life of an Engineer, Scholar and Public Intellectual », South Asia Multidisciplinary Academic Journal [Online], Free-Standing Articles, Online since 11 March 2019, connection on 20 May 2019. URL : http://journals.openedition.org/samaj/5021 ; DOI : 10.4000/ samaj.5021

This text was automatically generated on 20 May 2019

\section{$\Theta \Theta \Theta \Theta$}

This work is licensed under a Creative Commons Attribution-NonCommercial-NoDerivatives 4.0 International License. 


\section{Glimpses into the Life of an Engineer, Scholar and Public Intellectual}

Anand Teltumbde in Conversation with Roland Lardinois, November 2013-January 2019

Roland Lardinois

\section{Introduction by Roland Lardinois}

1 Anand Teltumbde is Senior Professor and Chair of Big Data Analytics at the Goa Institute of Management. He is a leading Indian intellectual and the author of several books on Ambedkar and the Dalits in India, including Khairlanji: A Strange and Bitter Crop (2008, New Delhi: Navayana). This book has been the subject of several reviews in France (Jaoul 2010, Cabalion 2010, Herrenschmidt 2014). It deals with the murder, in 2006, of a Buddhist, Mahar caste family, in the village of Khairlanji, in Madhya Pradesh. The perpetrators were peasants belonging to the dominant Kunbi caste and the victims, members of a Mahar caste family converted to Buddhism, thus belonging to the official Scheduled Caste, ex-Untouchable category, commonly known as Dalits. More recently, Anand Teltumbde published an essay on the functioning of caste in a democratic regime, entitled The Republic of Caste: Thinking Equality in the Time of Neoliberal Hindutva (2018, New Delhi: Navayana, with a foreword by Sunil Khilnani).

2 The conversation with Anand Teltumbde presented below does not directly address these issues, as the reasons for this talk are of a different nature, but he approaches some aspects touched upon in these books from a personal viewpoint. Conducting research on the history and sociology of Indian engineers as a socio-professional group, I wanted to talk with Anand Teltumbde about his family background, education, and professional experience in the industry where he spent the first part of his working life, before he joined a management institute in 2010 as an academic. 
3 Anand Teltumbde was born in 1952 to a landless peasant family, in a poor region of central India, Maharashatra-"My parents were landless." From the beginning, he does not seem to have the economic and cultural resources to pursue a higher secondary education, let alone gain access to university. Despite his good academic results from primary school onwards, his school years were full of difficulties, bifurcations and uncertainties. This is particularly true of his attempt to choose a vocational orientation after completing his higher secondary education. At the time, limited financial resources combined with a lack of information made it extremely difficult to clearly identify possible options in terms of a professional education-"We did not know at that time what engineering was." Enrolling in an Engineering College to obtain the degree of engineer requires, for example, the ability to distinguish this type of institution from a Polytechnic that awards an engineering diploma at the end of a two-year course. Anand Teltumbde finally obtained a Bachelor of Engineering, Mechanical (1973) from a college of good repute, the Visvesvaraya Regional Institute of Engineering in Nagpur. The acquisition of this diploma doubly sets Anand Teltumbde apart, first from his family, as his brothers and sisters did not study much, and then, from his village friends, his success making him everyone's "darling." This singularization also carries the risk of Anand Teltumbde distancing himself from his family milieu, or that it may, at the very least, become a source of misunderstanding, a sign of the new position that scholarly success entails in Anand Teltumbde's life story. Indeed, he was not unaware of his parents' poverty but he seems to have ignored it during his studies. However, the precariousness resurfaced when he was seeking financial support to enroll in a Master's degree at IIT-Kanpur. Despite his mother's positive response, his father's expectations were of a completely different order: "My father expected me to get a job."

Yet, it was not so much to satisfy his father's desire, but more because he did not have the means to continue his engineering studies, that Anand Teltumbde dropped his project to join IIT-Kanpur. He then went to Mumbai, and began his working life, doing a range of jobs, often for short periods at first, but he did not face many obstacles when he sought employment. His appetite for risk, his ability to break down barriers, and his engineering credentials were his main assets-"Job getting was not difficult for me." After various jobs with small mechanical contractors and a stint with a shipbuilding company, he joined Bharat Petroleum, a Public Service industrial group in the energy sector.

5 However, Teltumbde's desire to continue his studies did not disappear despite his inability to enter IIT-Kanpur after he received his engineering degree. In the early 1980s, the professional experience he acquired enabled him to join the IIM-Ahmedabad, where he obtained a PGDM (1982) and, ten years later (1993), he completed his university studies with a PhD in management from the University of Bombay: "doing a PhD remained a vague unfulfilled desire in me," he says. In 2010, after spending nearly four decades working as an engineer in the private and then public sector, Anand Teltumbde left the industry and became a teacher at the IIT-Kharagpur Business School (West Bengal).

6 The story of Anand Teltumbde's life describes a school, professional and social journey completely different to the simple reproduction of a given family situation. But it is not quite the model of rapid and direct success that would make a child from a poor family an educational miracle. ${ }^{1}$ However, we should avoid any kind of teleological reconstruction. In this case, each stage of the journey does not imply the need for the next stage.

7 Furthermore, this life story allows us to question how a change of place affects the relationship between Anand Teltumbde and his family background of landless peasant. 
He recounts how his feelings were awakened by the experience of economic inequalities, his demand for social justice and his discovery of Marxism coupled with that of Ambedkar's writings-"I was born in the den of Ambedkarism." At a very young age, "I was barely 10 years old," Anand Teltumbde made his first discovery of Marxism by reading a small book on Stalin's life, which he received for his good academic results in primary school. Teltumbde suggests that the teacher bought this booklet because of its low price rather than its content. He then passionately deciphered Ambedkar's books, which he found at the Nagpur University Library. From this time onwards, this double intellectual encounter nourished Teltumbde's thinking and in his analyses of socio-economic conflicts he favored a Marxist understanding in terms of class rather than caste. But he refused to participate in party activities, whether communist or Ambedkarist: "I did not see a compelling reason to join any party."

8 At this point, the reader may be surprised to note that no mention has yet been made of the caste to which Anand Teltumbde belongs, and he finally evokes it much later in the conversation: "I am from Ambedkar's caste: Mahar." That he chooses to provide this information at such a late stage can be associated with the admission that goes against both the interlocutor and the reader's expectations of caste discrimination that groups belonging to the former Untouchable community, the Dalits, usually suffer: "I may surprise many but I did not suffer much caste discrimination."

9 Looking back over his academic and professional experiences, Teltumbde shows, with finesse, that one must be careful not to hastily interpret any negative action or behavior towards Dalits as an immediate and direct form of caste discrimination. Not only must we be attentive to the context of the interaction in which discrimination can occur, we must also consider other factors (education, skills, class situation) that cannot be directly reduced to caste assignment.

We must hence respect Anand Teltumbde's statement: "I was not typified." Referring to Erving Goffman's work, as a sociologist one could be tempted to translate this expression into: "I have not been stigmatized." While the notion of stigma immediately comes to mind in the case of the former Untouchables, by implicit association with the idea of purity and pollution, Anand Teltumbde's statement is significantly different. It means, literally, "I have not been typified," that is, catalogued as a type, that of Scheduled Caste. As Teltumbde points out, his surname does not have immediate Scheduled Caste connotations. In addition, he recounts that he never mentioned his caste origin in interactions, particularly when he was a student at Visvesvaraya Regional Engineering College, so much so that his classmates wondered how to classify him in terms of caste. Finally, Anand Teltumbde almost never used the Scheduled Caste quota in the course of his studies, let alone in his professional life. This fact deserves to be highlighted in view of his commitment to the Dalits. And this allows Teltumbde to question the quota policy. Faced with criticism for opposing it, he highlights the caste issues underlying the reservation system and defends the implementation of an equal access to quality education policy for all groups in society: "What the Dalits should be fighting for is to have education of equal quality made available by the State to all children".

11 This analysis excludes any feeling of guilt or moral judgment from Teltumbde's remarks, emotions which so often give rise to the need for educated people belonging to the Scheduled Castes, to "pay back to society." "Society" in this case being a nebulous group of origin (the family, the lineage, caste associations, or other benevolent associations). On the contrary, it is as if, by independently acquiring an education and university degrees, 
Anand Teltumbde had given himself the means to position himself in a space of free discourse regarding the Dalits, taking into account collective and individual complexities - "I was still trying another way of changing things."

(I am grateful to Anand Teltumbde for this conversation that I recorded at IIT-Kharagpur on November 15, 2013; the transcript of this talk was reviewed, completed and edited by Anand Teltumbde through email exchanges in January 2019).

\section{"My parents were also landless"}

13 I come from a very remote village in Yavatmal district in Maharashtra [Amaravati Division], $150 \mathrm{~km}$ from Nagpur, at the border of Telangana State. Yavatmal district is famous for farmers' suicides, it is a dry land farming area, people are landless; my parents were also landless. So it is an accident that I was a very good student at school. Those days, Engineering was a coveted branch and only meritorious students aspired to it, hence by virtue of being a good student I ended up at an engineering college. Probably I was one of the first few people from my district to join an engineering college. We were eight brothers and sisters including me, and I was the eldest. All of them are not very educated. Excepting myself and my sisters, all have studied just about up to matriculation. Our area has coal mines; all my brothers are employed in these mines around the village itself or in the vicinity.

I did my schooling in my village school up to $7^{\text {th }}$ standard, and at the taluka high school up to $10^{\text {th }}$ standard [Matriculation]. After $10^{\text {th }}$ you had to go to Pre-University (PU) College. There were two streams to get into engineering. Either you could gain admission to Engineering College in the second year of PU, or you had to do a first year at a Science College then switch to Engineering College. After class 10 there was PU for me and thereafter you had to do a first year of Bachelor of Science (BSc). Only then you could apply to Engineering College.

There was another stream, which was higher secondary education, that is class 11, but it so happened that in our school it was not available. So we had to pass out with matriculation, then take admission in Pre-University in Science College. But other people who went through $11^{\text {th }}$ standard could get admission into the first year of BSc and again, depending upon the stream they had entered, they could go to medical or Engineering College. If they had taken Physics, Mathematics, Chemistry streams, they would land up in engineering, if they had taken Biology and Botany (non-mathematical stream), they would land up in Medical College. That was the system at that time. It changed when I passed my Pre-University.

In Nagpur, I did engineering at the VRCE, Visvesvaraya Regional Engineering College (now Visvesvaraya National Institute of Engineering); it was a five-year integrated course. Now it has become four years after class 12. After I passed Pre-University, as I applied on merit, I got admission there. Only two people from the Pre-University stream got admission, because the standards of pre-university and the $11^{\text {th }}$ Board Exam were very different. There was a major filtration process at this PU level. Very few people used to pass. So most of the people who came from class 11 were admitted, but only two people from the PU class got admission in the first year of Engineering. 


\section{"We did not know at that time what engineering was"}

17 I was travelling for the first time to a big city like Nagpur and it was fairly difficult, like for any villager who does not have any relatives living in town. It was the first time I was leaving the taluk. Initially I faced a lot of difficulties, on account of not applying for hostel admission and hence having to stay outside. The first year, I just had a vague idea that I should go to an Engineering College. I had gone asking the rikshawallas for an engineering college and they left me in a queue for admission to a Polytechnic College, as they were known in those days. After I filled up the form and reached the counter I realized it was a Polytechnic College! We did not know the difference between a Polytechnic and an Engineering College. I went all the way back and filled up the form at the College of Science. For a couple of days, I stayed with a family related to one of my friends. I did not know I had to fill up the hostel form, so when I came to join the College, there was no hostel to stay in. I presumed that when you got admission they would give you hostel accommodation too. This mistake caused me great hardship for some three to four months, then I managed to shift to the hostel. Along with one of my classmates, I rented a room very far from the College and from there I used to walk something like 5 to $6 \mathrm{~km}$ to College, and back again. I did not have any money and I shudder to remember how I spent those days in a half-starved state. Only after I got admission to the hostel my travails came to an end. I got scholarships, right from school. This covered most expenses but had to be supplemented by my parents. They did it somehow. You cannot cogently remember how, just working as laborers, they did it - feeding a family of ten people, educating my seven siblings and then me. After the initial hiccups, I began taking an interest in students' politics and was catapulted into several actions. This continued through my engineering studies for five years and beyond.

\section{"My father ... expected me to get a job"}

18 After graduating from engineering college, I got a job through campus placement, but I could not join because I was sick all through the exams with hepatitis. Moreover, I was not mentally prepared to do a job and wanted to go for post-graduation. I thus applied, and got admission for MTech at IIT-Kanpur. I joined the course, but I did not have the money to pay the fees and other upfront payments. When I asked my parents for money, there was no response. So I had to return home. It was not surprising but then I learnt that my parents were broke. Already, they had accumulated significant debt in the expectation that I would get a job and resolve the financial crisis. My father had graduated from laborer to cloth peddler for a village shopkeeper. He did various kinds of businesses alongside. Engineering sounded big to villagers and my father just imagined that there would be a big flood of money after I took a job. My mother, of course, was supportive when I wished to join IIT-Kanpur. Although my education would have been financed by a scholarship, at that time it was Rs. 400 per month. I understood the situation and one day, after a minor quarrel, I decided not to go back to Kanpur. I left home and went to my maternal aunt whose husband was posted at Wadsa in Chandrapur district [East of Maharashtra], and then headed off to Bombay with her introduction to her friend in Majiwada (Thane). There were many engineering companies in the vicinity of Majiwada, I would just walk in with my mark sheets in my pocket, and they were 
impressive enough to get me a job. But with my unstable mental condition, I would only last a few days and then hop to another.

\section{"Job getting was not difficult for me"}

19 I worked for 10-11 months at as many companies in that belt. Significantly, I worked at Blue Star, an Air Conditioning company. I just walked in, convinced the chowkidar [guard] to let me into the office and I talked to some people saying I needed a job badly. This was my modus operandi to seek a job. Those days were not as bad and people did cooperate after their initial apathy. Someone would take me to somebody dealing with recruitment and after looking at my marks they would get serious and lead me to an engineering head. The head of Blue Star engineering exclaimed, "Oh so brilliant!" and immediately asked me to come from the next day.

I did a good job there. On my own initiative, I suggested designing a domestic water cooler and the head of engineering approved my idea and offered to help me. I singlehandedly designed a compact water cooler, about the size of the earthen pot Indians had those days for cold water. I developed the bill of materials, revised my design in accordance with the available materials and got down to making a prototype with the help of workers and technicians who were about my age. There was nothing official, yet these people would spend extended hours for me and contribute their might to my project. It was a huge learning experience in interpersonal behavior, as well as a study of working class behavior, quite different to the professionals. I created a prototype within three to four months, I think. They had promised me they would raise my salary, but when the time came the head of engineering, who was extremely pleased with my work, probably could not manage it. I went to the president and quarreled with him and left the job. I resumed my usual round of going from job to job again. Except for Blue Star, the duration of my stay averaged 15-20 days. I was in an extremely unstable mental condition, precariously living off small money, staying with a family that was very affectionate but poor. Their house was a slum dwelling and they arranged a cot in the veranda for me to sleep on, with lots of bedbugs.

Then, I landed up at Mazagon Docks Ltd. a ship-building and ship-repairing company in the Public Sector, as a Graduate Engineer Trainee, a typical designation then for fresh engineering graduates. The job brought me full-fledged responsibility with other senior engineers. There was a bond to serve the company for three years. Although the job was good, Bombay was a difficult place to stay. I had applied for many other jobs and they started materializing soon after. Whatever job I applied for, actually materialized. That's how I got a job with Indian Oil Corporation, which was considered very good back then. In those days, they had a reputation of being good paymasters, and besides the salary, they paid a bonus that went up to one and half times the salary. I left Mazagon Docks and joined Indian Oil in Bihar, at the Barauni Refinery, as an Engineer. Mazagon Docks started harassing me to reimburse what I owed for breaking the bond. I was innocent and did not have the wherewithal to get into legal hassles. I had to collect money to pay them. So I paid that bond amount, and stayed with Indian Oil, reaching Senior Engineer level. In 1980, I left Indian Oil and went to IIM-Ahmedabad. I was told I had done extremely well in the exam and hence got through all the interviews at all three IIMs, both for the MBA (PGDM) and PhD (Fellowship). Ultimately, I did my MBA and left. In my second year 
thanks to references from my professors, I was doing some consultancy assignments for companies and earning money. Since I was still employed by Indian Oil, I could not participate in campus placement. Some private companies, however, came to me and interviewed me privately. One such company, an owner-managed group, approached me and offered me a job, which looked quite good, and they promised the best pay packet on the campus. I took the risk and left Indian Oil to join the Khandelwal Group, whose headquarters are in Bombay. My job was that of management consultant to the owner, who wanted some investment opportunities. But after joining, I discovered to my discomfort that they were not at all professional. I had a good equation with him but he suddenly died. I had also decided that it was not good to stay there and I was on the lookout for a suitable switch. Luckily, a few days after his death, a job materialized at Bharat Petroleum, a PSU [Public Sector Undertaking], as manager. I accepted a fraction of what I got in exchange for time to pursue my other interests, working for people. This was in 1983. I worked for them in various capacities until 2003, and was Executive Director at the time of leaving. After India adopted the neoliberal economic reforms, the cash rich PSU oil companies floated many joint venture companies in the private sector. The main motivation was to avoid the regulatory shackles of the government over the PSUs. It is interesting that dozens of these Joint Ventures [JV] flopped and the PSU companies lost millions in investments. Nothing, however, was made public. The government, however, took the lead in searching for a person to head it and in the process I got the job. I was to be the Managing Director and CEO, with five JV Companies under me. The business model conceived for the company was grossly faulty but in the hope that I would be able to correct it, I accepted the offer and joined Petronet India Limited in 2003. Soon after, the company suffered conflicts of interests from the member companies. This reached a climax in 2010 and I hence I left the company.

While working with Bharat Petroleum I did my PhD in Management. My work was related to modeling public system problems using cybernetics. I did not have any particular reason to do a PhD except that it remained a vague unfulfilled desire in me, but this took me back to the academic sphere. In that phase, I went around writing papers, reading them at international conferences, and publishing them in journals. With the help of some friendly professors at my alma mater, IIM Ahmedabad, I taught as Visiting professor and gave guest lectures at other times. One of the professors had joined the Business school of IIT Kharagpur as dean and he managed to get me an invitation from the institute to join the faculty. I thought of not taking up a job and concentrating on writing but I could not resist his affectionate call and joined IIT Kharagpur in 2010.

\section{"I was born in the den of Ambedkarism"}

24 I was born in a region, which came to be the den of Ambedkar's movement. Those were the times when Ambedkar's influence was pervasive. Except for the folklore about him, there was nothing to read. There was only a lesson in a school text book, which was a transcription of Ambedkar's reminiscences about his childhood, documented by some professor. Beyond this, there was no way to know what he taught, what he did. There was nothing, beyond folklore. I was not interested in folklore myself.

The first opportunity came when I reached Nagpur. After I got admission to the Science College hostel, I had enough respite to go to the university library where I found books by Ambedkar. I decided to read them. I made it a point to rush to the library with a 
dictionary as soon as my classes were over, and sat reading Ambedkar until the library closed. In the process, I missed most dinners at the hostel mess and managed with some food from street joints close to the hostel. I made exhaustive notes while reading and mulled them over after returning to the room.

Slowly books on Ambedkar started appearing but they were little better than the existing ones. Now there are books, purportedly research into his various thoughts. There are biographical accounts too. It all began in the late 1960s. Many factors coincided to bring about this change. Most significantly the first generation of Dalit University graduates appeared and came face to face with the bleak reality; they began articulating their unease taking inspiration from the Black literature movement in the USA. A new genre of literature began to emerge and with it there were also books written on Ambedkar. This coincided with the beginning of the Dalit Panthers, and Dalit literature written by unemployed students. This period was the period of youth uprising all over the world. The Dalit students and their Dalit literature evolved into an off shoot, with the "Dalit Panthers" taking inspiration from the Black Panthers in the USA. Objectively speaking, the Dalit Panthers was a short lived phenomenon, but it created a disproportionate impact, bringing the Dalits into the national agenda. Ambedkar was gradually iconized, and although Ambedkar was largely ghettoized by the Dalits, his iconization was a catalyst for general awareness, the institutionalization of things like Ambedkar studies, and through that, literature on Ambedkar.

\section{"I was still trying another way of changing things"}

27 I had always pursued activism, in parallel, right from my schooldays to my academic achievements. Somehow, this began in my village. As a child I was intrigued by inequality between people: some people had big homes, land, cattle and everything, whereas others like my parents did not have anything. I found my parents working so hard but some people were just idle. I was uncomfortable with what appeared to be natural. As a child, I brooded over why we did not have what others had, land, good houses, cows, goats, chicken, the kind of things that a village child is interested in. The basic quest to find answers to these things pushed me to excel, as well as towards activism. The Ambedkar folklore showing him as a great scholar was inspiring. As I grew up my activism also grew. It became my parallel career.

There was a sort of accident that had a great impact on my life: receiving a short biography of Joseph Stalin as a prize for my excellent results in $3^{\text {rd }}$ standard. It touched a chord with me. I felt it answered many of my questions. I thought communism was the way to walk. In the general elections that took place at the time, I mobilized all my friends in school and painted the walls to ask for votes for the communist candidate. We canvassed so hard that the candidate got an abnormal number of votes from our village. It was all voluntary! I was just a child then, maybe 10 years old. I was not, and never have been, a member of, or associated with any political party, even with the Ambedkarite one. The more I thought through these things, the more was I convinced that no radical change would be possible within the existing framework. I was not convinced by the model, I was still trying another way of changing things. In school I identified with the communist party and did not see any contradiction with the Dalits' Republican Party. But by the time I reached College, I confronted the leaders of this party in the context of college elections. Then I realized that these leaders did not share the vision I had, of 
bringing about a revolutionary change and were just interested in elections. They wanted me to join the party, but I did not see a compelling reason to join any party.

\section{"Dalit was a different matter"} read Ambedkar and began appreciating his thoughts and struggle. I thought Ambedkar's struggle was fundamental as far as the oppressive caste system was concerned but that it should have been waged within the macro framework of Marx's class struggle. I did not see any contradiction between the two. I did not even know that the so-called Ambedkarite leaders were treating communists as the enemy and were scheming to break the party with these pretexts. Amazing, but this teenage insight remained with me, validated by accumulated experience. Unfortunately, even today there are few people, both in the Ambedkarite and the communist camp who share these views with conviction.

31 I was never affiliated to any of the radical political groups that were born during my college days. In 1968, there was an armed uprising in Naxalbari, and we were quite enthused by the revolutionary prospects it reflected. There used to be long discussions on these developments in hostels. We heard many engineering campuses were affected in Bengal, and many other States. The closest regional Engineering College at Warangal had become a hotbed of student activities inspired by this movement. But we did not scale up to that level. The movement in Naxalbari was brutally suppressed by the government, interestingly led by the communists.

\section{"I was not typified"}

It may surprise many, but I did not suffer much caste discrimination. Ours was a typical village neatly segregated on caste lines. People did follow untouchability but then it was internalized by everyone. Dalits had begun to resent it but not much had changed. The conversion to Buddhism had generated a wave of assertion. Personally, I think I was seen differently by the entire village because of my school performance. I was a kind of darling of the entire village.

At the level of Standard 4 and 7 there used to be a common exam at the panchayat level. There was a competitive spirit among schools, and in turn villages, who wanted a student from their village to come first. In my times, I had gained such fame that no one could beat me in the exams. I would always get cent percent marks. Because of this I was 
treated as an asset to the village. The customary practice of untouchability was followed by most people unconsciously but I do not think there was discrimination. Our teacher of course was non-Dalit, but he would call all the students to his own house to teach them. I don't really think that I faced it in early childhood.

Even when I went to a taluka level school-it was a very elite type of high school that only admitted meritorious students-I do not have any memories of being discriminated against. It was dominated by rich Brahmins and the upper castes. I was a new entrant in the school in standard 8. The class was divided into five groups and the top rankers were made the group leaders. I was made a leader of the largest group of newly-admitted students, the majority of whom were from villages. This was because in the first exam itself, I had stood first which-someone coming from a village standing first in that school -had never happened before. It was always a monopoly of Brahmin students' or wellbred, rich students' who used to have private tuition. My task was to check assignments and tutor weak students in my group. I had sensed that the class teachers favored good students, who invariably had tuition. I would not immediately attribute it to caste, as others lazily do. To a large extent, caste is a complement of class. Even at that age I thought certain things were not in my control and probably I could not change them. Why not just overwhelm them with performance? It worked for me. It is not that I did not suffer, but at the same time, the teachers could not ignore me.

But discrimination against the common folk used to exist. Again, it was not in palpable terms. Teachers would not pay attention to them, they would look at them derogatively; they constituted a sort of lowest strata, as in a normal class. Then again, when I went to the Institute of Science, I did not have to use any caste certificate as it was not necessary. Again in Nagpur my surname was not typically identifiable with that of Dalits. I was not moreover, on the list of SC candidates. Most of my close friends were Brahmans. I had that kind of benefit at both levels. I was not typified.

\section{"I am from Ambedkar's caste, Mahar"}

I am from Ambedkar's caste, Mahar. This was at Engineering College, when one leaderlike Dalit student, my senior, wanted to form an association in Ambedkar's name. Though I mingled with Dalit students and took as much interest in their discussions, they perhaps were unsure of my caste. He too had a doubt about my caste. I had to tell him that I was one of his. I was well known on the campus and used to win the students' gymkhana election with record margins. I used to conduct tutorial classes for my own classmates, for certain subjects considered difficult. Thus, I had huge good will and popularity on campus.

I was in the third year of Engineering. There was no other Dalit student in general politics then. Probably I was the first person to make a mark in general students' politics and that too with record votes. I also had a dubious reputation of being someone the Principal listened to. He was a terror on the campus and most professors were also scared to face him. This man, however, would just call me whenever any student issue had to be discussed. Anybody raising any student issue would be directed to me.

This boy wanted me to found this association with him. A lot of things involving interfacing with the administration could be easily resolved only by me. I delayed the foundation of the association by asking probing questions on the draft he created and 
making him revise it half a dozen times. The association was eventually born and was named Babasaheb Ambedkar Engineers Association. Today they call it Babasaheb Ambedkar National Association of Engineers. With this brief history, I would not call myself its founder, although I played a crucial, catalytic role in its foundation. Its actual founder was that boy, BM Meshram. He was the first president and I was the second. Today, very different people claim to be its founders and none knows this piece of history.

\section{"Caste operates in that way"}

In the corporate sector, very different games are played around caste. I got married while I was with Bharat Petroleum, My wife happens to be a grand-daughter of Dr. Ambedkar. From thereon I started being identified as a Dalit. Some Dalit employees had formed an $\mathrm{SC} / \mathrm{ST}$ association which I presided over for a few years. I was the most senior among them and hence they wanted me to take it over. I was initially reluctant because I was associated with organizations based on class politics and had decided to not associate with caste-based politics or groups. But after sensing that the company was not complying with whatever was statutorily applicable to the SC/ST employees, I decided to take it over and orient it to join hands with the general workers' union. I held meetings with the general workers' union and sensitized them to why they needed to support the $\mathrm{SC} / \mathrm{ST}$ employees in their struggle, and how they would be part of the general struggle against the management. It was embarrassing to the management as I was myself at senior management level. They took the decision to transfer me to Chennai. They thought I would understand the lesson but I coolly packed my bags and went to Chennai.

Having gone to Chennai, I not only continued my activities but intensified them by starting a bulletin called Sparklet. Generally, most SC/ST organizations petitioned management and the latter favored them to gain their confidence to perpetuate their discriminatory policies. I knew this dynamic and hence instituted a new mode of discussion with the management and collective decision making. On certain statutory provisions, we did not compromise and filed cases in the High Court. I did suffer in my progression but that is the price one has to pay. It may be attributed to caste but I would not see it that way. Because, in order to dampen me, the management would promote some other incompetent Dalit employee. Instead of asking me as a representative to sit on committees as statutorily mandated, they would take some more pliable Dalit employee. This is the typical method the management uses anywhere in relation to Dalits, and it uses Dalits as "stooges" as it did in politics. A person like me, whatever caste he belongs to, is not easily accepted because I could not be taken for granted. As I joined the company by virtue of my qualifications and experience, I would have been the Chairman of that company long before anyone else.

This caste dynamic escapes stereotypical discussions on caste. Caste operated as a system of premium and discount. If you are identified as Dalit, you are discounted. But if the larger system finds the Dalits useful, it will treat him/her as a premium. When this dynamic works in relation to other Dalit employees, it may be said to be a caste issue, but when it is generally accepted that SC employees are more docile, more obedient, and more faithful to those in power, as they are in politics, it is certainly a secular issue/ consideration. 

armchair academics certainly mars an understanding of them. It is certainly not straightforward as it is made out to be. If you are a Dalit of mediocre standing the chances are you are compliant with the management structure. If so, you get premium treatment. You will be favored over the others, invariably the more competent Dalit employees. Management primarily needs people who fall in; not people who question. As far as the statutes are concerned, they need such employees to demonstrate that they do not discriminate on the basis of caste. They need them to sign on the dotted line. Caste, when seen as a salient factor in discrimination, is actually mixed up with many other considerations, which are easily ignored. It is not ever just caste, but involves other attributes that are equally influential in the process of discrimination. That is the way contemporary caste needs to be understood but there is so much intellectual inertia. If you are a very confident and qualified Dalit, chances are you would not like to be taken for granted. You are sure to suffer in Indian organizations unless you mend your ways. When I was selected amongst the 20 people who contributed to the development of the Indian IT industry, my own company was not happy to acknowledge it. When I was rewarded with the Best CIO Award [Chief Information Officer Award] by the Bombay CIOKlub, the director of my company had such a complex that he announced on stage that the company did not have a CIO position. Nobody, however, would say that I am not a competent person because it would violently clash with the objective truth. In the course of time, such competent Dalit employees either strike compromises with the management, or they are demoralized and reduced to deadwood, augmenting the caste prejudice that Dalit employees are incompetent. I have explained this dynamic in relation to reservation-how the premise behind the reservation system is ill-founded-and how its operation further compounds the error, making its net result detrimental to Dalits.

\section{"Why should they go through reservation?"}

I belong to the first generation of Dalits. Generation refers to the educational and employment status of your parents. If your parents were illiterate and were not in government service, you would be called a first generation Dalit in the job market. The majority of Dalit boys and girls coming to IITs and IIMs today are second or third generation Dalits. Most of them come from a good background. They however suffer a stigma if they avail of the reservation. These days, reservations are given to $\mathrm{OBCs}$ too, but only Dalits are stigmatized.

Reservation, I guess, does subtle psychological damage to Dalits students in premier institutes. I am generally seen as an opponent to the reservation system but what I say is not against reservation. I am exposing the politics behind it; how reservations have been weaponized by the ruling classes to divide the people, to strengthen caste consciousness. I do contend that reservations are not a panacea. What the Dalits should be fighting for is for the State to provide equal quality education to all children through a common school system, preferably through neighborhood schools. This should be applicable to all children up to the age of 18 . Even thereafter, education should be free up to graduation and provided by the State. When education in India is multi-layered, no amount of reservation can remove the basic rot. It is only after instituting such preliminary tasks that reservation can be implemented meaningfully.

South Asia Multidisciplinary Academic Journal , Free-Standing Articles 


\section{BIBLIOGRAPHY}

Cabalion, Joël. 2010. “Anand Teltumbde, Khairlanji: A Strange and Bitter Crop, New Delhi, Navayana, 2008, 214 p." La Vie des idées, July 1. Retrieved March 11, 2019 (https://laviedesidees.fr/Laviolence-de-caste-en-Inde.html).

Herrenschmidt, Olivier. "Violence d'un autre âge dans les villages indiens. Actualité d'Ambedkar. À propos de: Anand Teltumbde, The Persistence of Caste: The Khairlanji Murders \& India's Hidden Apartheid, London, Zed Books Ltd, 2010, 192 p." European Journal of Sociology / Archives européennes de sociologie 55(1):59-81.

Jaoul, Nicolas. 2010. "Anand Teltumbde, Khairlanji: A Strange and Bitter Crop." South Asia Multidisciplinary Academic Journal. Retrieved January 28, 2019 (http://journals.openedition.org/ samaj/2937).

Naudet, Jules. 2015. Entrer dans l'élite. Parcours de réussite en France, aux États-Unis et en Inde. Paris: Presses Universitaires de France.

Naudet, Jules. 2018. Stepping into the Elite: Trajectories of Social Achievement in India, France and the USA. Translated by R. George. Delhi: Oxford University Press.

\section{NOTES}

1. For a comparative view of Anand Teltumbde's life story with other educated Dalit trajectories, see Jules Naudet, Stepping into the Elite: Trajectories of Social Achievement in India, France and the USA (2018), translated from the French by Renuka George (Entrer dans l'élite. Parcours de réussite en France, aux États-Unis et en Inde [2015]).

\section{ABSTRACTS}

An engineer by training, a scholar presently teaching at the Goa Institute of Management, and a public intellectual who writes on Dalit issues, Anand Teltumbde opens up about his life experience. Coming from a landless family living in a dry village of Maharashtra, Teltumbde, who was a good pupil at school, succeeded in pursuing higher-level studies and received first a BTech, then an MBA and finally a PhD. He recounts his personal experience working as an engineer in small enterprises in Mumbai before joining the public sector as a manager. Meanwhile, Teltumbde who was born in the "den of Ambedkarism" recalls his involvement in the Ambedkar movement, although he was never a regular member of any political parties or associations. In this interview Teltumbde expresses his views that the reservation system is no panacea, but Dalits and the depressed classes should benefit from equal-quality education for all, provided by the State. 
INDEX

Keywords: Ambedkar, Dalits, education, engineer, Maharashtra

\section{AUTHOR}

\section{ROLAND LARDINOIS}

French National Center for Scientific Research (CNRS), Center for South Asian Studies (CEIASEHESS) 